\title{
Aseptic meningitis caused by Leptospira spp diagnosed by polymerase chain reaction
}

\author{
Eliete Caló Romero ${ }^{1 /+}$, Roberta Morozetti Blanco', Paulo Hideki Yasuda ${ }^{2}$ \\ 'Laboratório de Leptospirose, Seção de Bacteriologia, Divisão de Biologia Médica, Instituto Adolfo Lutz, \\ Av. Dr. Arnaldo $3559^{\circ}$ andar, 01246-902 São Paulo, SP, Brasil ²Departamento de Microbiologia, Universidade de São Paulo, SP, Brasil
}

\begin{abstract}
Leptospirosis is a zoonotic disease caused by the pathogenic Leptospira spp. The clinical presentations are diverse, ranging from undifferentiated fever to fulminant disease including meningeal forms. The neurological leptospirosis forms are usually neglected. The aim of this study was to investigate leptospirosis as the cause of aseptic meningitis using different diagnostic techniques including the polymerase chain reaction (PCR). Thirty-nine cerebrospinal fluid (CSF) samples from patients presenting with meningeal abnormalities, predominance of lymphocytes and negative results by traditional microbiological tests were processed by leptospiral culture, anti-leptospiral antibody response and PCR. Leptospira spp DNA was detected in 23 (58.97\%) of the CSF samples. Anti-leptospiral antibodies were found in $13(33.33 \%)$ CSF samples. Twelve CSF samples were positive by PCR assay and negative by microscopic agglutination test (MAT) assay. Two CSF samples were positive by MAT and negative by PCR. The positive and negative agreement between both tests was 11 and 14, respectively. CSF samples from six cases of unknown diagnosis were positive by PCR assay. Eight cases showed positive results using PCR and MAT. Leptospirosis could be detected by PCR assay from the 3rd-26th day after illness onset. The sensitivity of the PCR was assessed with confirmed cases of leptospirosis (by MAT) and found to be $89.5 \%$. All CSFs were negative by culture. PCR was found to be a powerful tool for diagnosing meningitis cases of leptospirosis. We recommend that it may be used as a supplementary diagnostic tool, especially in the early stages of the disease, when other diagnostic techniques such as serology are not sensitive.
\end{abstract}

Key words: Leptospira spp - leptospirosis - aseptic meningitis - CSF - PCR - diagnosis

Leptospirosis is a zoonotic disease of worldwide distribution caused by pathogenic spirochetes of the genus Leptospira (Faine et al. 1999, Levett 2001). The disease is one of the major causes of morbidity and mortality worldwide (WHO 1999). Brazil has about 3,000 confirmed cases of leptospirosis annually (MS 2007). The clinical presentations are diverse, ranging from undifferentiated fever to fulminant disease. Anicteric leptospirosis is the most common, occurring in $80 \%$ of cases (Faucher et al. 2004). Meningitis can occur (Sperber \& Schleupner 1989, Gollop et al. 1990, Torre et al. 1994, Romero et al. 1998, Silva et al. 2002, Karande et al. 2005, de Souza et al. 2006, Merwick et al. 2008) and this form of leptospiral infection can be confused with other aseptic meningitis (Nelsen et al. 1993, de Almeida et al. 2007). The neurological leptospirosis forms are usually neglected. Although the majority of the cases of meningitis caused by Leptospira spp are benign (Beeson \& Hankey 1950, Bigham 1953), this form of leptospirosis can be fatal (Kitaoka et al. 1976).

Meningeal involvement in leptospirosis is biphasic. In the early phase, which lasts approximately seven days, leptospires can be cultured from the cerebrospinal

+ Corresponding author: ecromero@ial.sp.gov.br

Received 23 April 2010

Accepted 20 September 2010 fluid (CSF). In later phase, diagnosis can be made with immunological tests (Feigin \& Anderson 1975). Differentiating between leptospiral meningitis and other forms of aseptic meningitis is a challenge in endemic regions such as Brazil. Rapid detection is important for the recommendation of an appropriate treatment; however, the diagnosis of leptospiral meningitis is often difficult. An initial presumptive diagnosis is normally made on the basis of the clinical presentation and CSF biochemistry. The diagnosis of leptospirosis is confirmed by blood or CSF culture and/or the presence of antibodies in the CSF or in serum samples. The culture requires 13 weeks to provide a result, limiting its value in aiding diagnosis and immediate decisions on treatment (Levett 2001). The conventional method for detecting specific anti-leptospiral antibodies in CSF or in serum samples is the microscopic agglutination test (MAT). However, agglutinating antibodies are not detected in the early phase of the disease and the test is not efficient for patient management (Mathew et al. 2006). Thus, the information needed for specific antimicrobial therapy is unavailable for the first few days of the disease. The polymerase chain reaction (PCR) is becoming a common diagnostic tool for the early and accurate diagnosis of bacterial meningitis ( $\mathrm{Ni}$ et al. 1992, du Plessis et al. 1998, Romero et al. 1998, Bäckman et al. 1999, Lorino et al. 1999, Margall Coscojuela et al. 2002, Saravolatz et al. 2003, Avery et al. 2005, Zambrano et al. 2006). The objective of our work was to determine if Leptospira spp was the etiologic agent of aseptic meningitis using different diagnostic techniques, including PCR. 


\section{PATIENTS, MATERIALS AND METHODS}

Patients - Between March 1999-April 2003, CSF samples were obtained from hospitals in São Paulo (SP), Brazil, from 39 hospitalized patients who presented meningeal abnormalities in differential diagnosis, predominance of lymphocytes and negative results in traditional microbiologic tests. The differential diagnosis included bacterial and viral meningoencephalitis, sepsis, malaria and cerebrovascular disease. CSF was collected by lumbar puncture during the acute phase of the disease and transferred to a new and sterile tube as soon as the patients were suspected of having meningitis. The study was done in a prospective manner, although there was no active systematic surveillance for leptospirosis meningitis in the hospitals. CSF samples were processed for leptospiral culture, MAT and PCR. Upon arrival at the laboratory, $200-400 \mu \mathrm{L}$ of each CSF sample was sterilely removed and stored at $-20^{\circ} \mathrm{C}$ until further processing with DNA extraction and PCR. The remaining CSF was used for standard routine analysis, i.e., leptospiral culture and detection of antibodies by MAT. Attempts were made to obtain patients' serum samples from the acute and convalescent phases. This study was approved by the Ethical Committees of the Brazilian Ministry of Health and the Adolfo Lutz Institute.

DNA extraction and PCR - For DNA extraction, $100 \mu \mathrm{L}$ of the CSF was centrifuged at $13,000 \mathrm{~g}$ for $15 \mathrm{~min}$ and washed twice with $100 \mu \mathrm{L}$ of Milli-Q water. After centrifugation, the supernatant was discarded and the pellet was resuspended in $20 \mu \mathrm{L}$ of Milli-Q water. Samples were boiled for $10 \mathrm{~min}$, cooled to room temperature and then centrifuged for $1 \mathrm{~min}$ at $12,000 \mathrm{~g}$. Ten microliters were used as the template in each PCR reaction. The extraction included water controls to rule out any contamination. PCR was performed using primers corresponding to nucleotides $38-57$ and 348-368 in the primary structure of the Leptospira interrogans rrs (16S) (A, 5'-GGCGGCGCGTCTTTAAACATG-3'; B, 5'-TTCCCCCCATTGAGCAAGATT-3'). The PCR assay was performed according to Mérien et al. (1992) with 35 cycles. Each run of the assay included a positive control, which consisted of Milli-Q water spiked with 10-fold serial dilutions of leptospires and a negative control consisting of Milli-Q water. All PCR assays were performed in three separate rooms and barrier tips were used to prevent carry over amplicon contamination. Samples were tested in duplicate. The amplification product was analyzed by $1.5 \%$ agarose gel electrophoresis stained with ethidium bromide. The sensitivity of the reaction was determined from $1 \mathrm{ng}-10 \mathrm{fg}$. The lower limit of detection of Leptospira DNA in the assay was $1 \mathrm{pg}$ by agarose gel electrophoresis. Agarose gel electrophoresis of the PCR products revealed the presence of a product of the predicted size for samples containing $10^{1}$ leptospires. The specificity of this PCR method has been previously described (Mérien et al. 1992, Romero et al. 1998).

$M A T$ - The test was used as a reference method (Faine et al. 1999) with the following serovars of Leptospira spp as antigens: Australis, Autumnalis, Bataviae, Butembo, Canicola, Castellonis, Copenhageni, Cynopteri, Djasiman, Grippotyphosa, Hebdomadis, Icterohaemorrhagi- ae, Javanica, Panama, Pomona, Pyrogenes, Shermani, Tarassovi and Wolffi. These serovars represent the most prevalent serogroups in SP (Sakata et al. 1992, Romero et al. 2003, 2009, Romero \& Yasuda 2006). Serovar Andamana was also used since it was isolated from CSF in Brazil (Corrêa et al. 1971). The following criteria were used to interpret the MAT results and define a confirmed case of leptospirosis: (i) the presence of antibodies against leptospires in CSF, (ii) a four-fold increase in titer of two serum samples collected between acute and convalescent phases and (iii) a minimum titer of 1:800 in a single serum sample. A probable case was defined as a patient with a single serum sample with a minimum titer of $1: 200$ or with two or more samples with a less than four-fold increase in titer. The predominant leptospiral serogroup was considered to be the one that gave the highest titer with $50 \%$ of free leptospires. MAT results were considered inconclusive when the same highest titer was obtained for two or more serogroups. A negative case of leptospirosis was defined as having negative MAT results in CSF and serum samples.

Culture - A volume of $0.5 \mathrm{~mL}$ of each CSF sample was inoculated into Ellinghausen McCullough Johnson Harris base medium supplemented with Bacto Leptospi$r a$ Enrichment (Difco Laboratories, BD, NJ) and 0.1\% agarose, incubated at $30^{\circ} \mathrm{C}$ for 16 weeks and examined weekly by dark field microscopy for the presence of leptospires (Faine et al. 1999, Levett 2001).

\section{RESULTS}

Thirty-nine patients with aseptic meningitis were examined. Figure shows the number of positive results for all tests according to the number of days after illness onset. PCR was capable of identifying leptospirosis from the 3rd-26th day after illness onset. The Table summarizes the results of the PCR and MAT assays, the age and sex

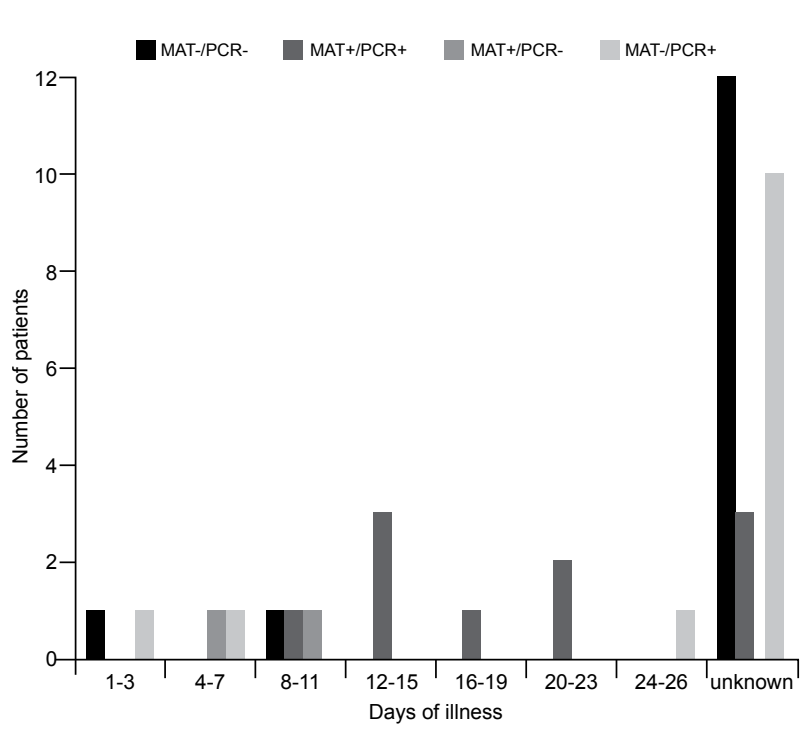

Distribution of polymerase chain reaction (PCR) and microscopic agglutination test (MAT) results for cerebrospinal fluid from 39 patients with meningeal abnormalities by the number of days after illness onset. 
TABLE

Results of serology by microscopic agglutination test (MAT) and cerebrospinal fluid (CSF) evaluation by MAT and polymerase chain reaction (PCR) from patients with meningeal abnormalities

\begin{tabular}{|c|c|c|c|c|c|c|c|}
\hline \multirow[b]{2}{*}{ Patient } & \multirow[b]{2}{*}{ Age } & \multirow[b]{2}{*}{ Sex } & \multirow{2}{*}{$\begin{array}{c}\text { Interpretation } \\
\text { of cases } \\
\text { based on MAT }\end{array}$} & \multicolumn{2}{|c|}{ Serology by $\mathrm{MAT}^{b}$} & \multicolumn{2}{|c|}{$\mathrm{CSF}$} \\
\hline & & & & 1st sample & 2nd sample & $\mathrm{MAT}^{b}$ & PCR \\
\hline 1 & 12 & M & Negative & Negative $^{a}$ & - & Negative & Positive \\
\hline 2 & 54 & $\mathrm{~F}$ & Negative & Negative $^{a}$ & - & Negative & Positive \\
\hline 3 & Unknown & $\mathrm{F}$ & Negative & No serum samples & - & Negative & Negative \\
\hline 4 & Unknown & M & Confirmed & Icterohaemorrhagiae & Icterohaemorrhagiae & Icterohaemorrhagiae & Positive \\
\hline 5 & 21 & M & Negative & Negative & Negative & Negative & Negative \\
\hline 6 & 40 & $\mathrm{~F}$ & Confirmed & Icterohaemorrhagiae & Icterohaemorrhagiae & Castellonis & Positive \\
\hline 7 & 12 & $\mathrm{~F}$ & Negative & No serum samples & - & Negative & Negative \\
\hline 8 & Unknown & $\mathrm{F}$ & Negative & No serum samples & - & Negative & Positive \\
\hline 9 & 32 & $\mathrm{~F}$ & Confirmed & Icterohaemorrhagiae $^{a}$ & - & Inconclusive & Positive \\
\hline 10 & 12 & M & Confirmed & Icterohaemorrhagiae & Icterohaemorrhagiae & Negative & Positive \\
\hline 11 & 10 & M & Confirmed & Inconclusive & Icterohaemorrhagiae & Negative & Positive \\
\hline 12 & 15 & M & Confirmed & Inconclusive & Icterohaemorrhagiae & Icterohaemorrhagiae & Negative \\
\hline 13 & 33 & M & Confirmed & Negative & Negative & Canicola & Negative \\
\hline 14 & 43 & M & Negative & No serum samples & - & Negative & Negative \\
\hline 15 & 30 & M & Negative & Negative $^{a}$ & - & Negative & Negative \\
\hline 16 & Unknown & M & Negative & No serum samples & - & Negative & Negative \\
\hline 17 & 24 & M & Confirmed & Negative & Pyrogenes & Negative & Positive \\
\hline 18 & Unknown & M & Confirmed & No serum samples & - & Inconclusive & Positive \\
\hline 19 & 20 & M & Negative & Negative & Negative & Negative & Negative \\
\hline 20 & 49 & M & Negative & Negative $^{a}$ & - & Negative & Negative \\
\hline 21 & 28 & M & Probable & Bataviae & Bataviae & Negative & Positive \\
\hline 22 & Unknown & M & Negative & Negative $^{a}$ & - & Negative & Positive \\
\hline 23 & Unknown & M & Negative & No serum samples & - & Negative & Negative \\
\hline 24 & 32 & M & Negative & Negative $^{a}$ & - & Negative & Positive \\
\hline 25 & 49 & M & Confirmed & No serum samples & - & Icterohaemorrhagiae & Positive \\
\hline 26 & 50 & M & Negative & Negative & Negative & Negative & Negative \\
\hline 27 & 3 & M & Negative & Negative & Negative & Negative & Negative \\
\hline 28 & 8 & M & Confirmed & Icterohaemorrhagiae & Icterohaemorrhagiae & Icterohaemorrhagiae & Positive \\
\hline 29 & Unknown & M & Confirmed & No serum samples & - & Inconclusive & Positive \\
\hline 30 & 17 & M & Negative & Negative $^{a}$ & - & Negative & Positive \\
\hline 31 & 33 & $\mathrm{~F}$ & Negative & No serum samples & - & Negative & Negative \\
\hline 32 & 14 & M & Confirmed & Negative & Icterohaemorrhagiae & Negative & Positive \\
\hline 33 & 34 & M & Confirmed & Icterohaemorrhagiae $^{a}$ & - & Inconclusive & Positive \\
\hline 34 & 52 & $\mathrm{~F}$ & Confirmed & Negative & Icterohaemorrhagiae & Icterohaemorrhagiae & Positive \\
\hline 35 & 39 & M & Confirmed & Negative & Autumnalis & Negative & Positive \\
\hline 36 & 10 & M & Negative & Negative $^{a}$ & - & Negative & Negative \\
\hline 37 & 14 & M & Confirmed & Icterohaemorrhagiae & Icterohaemorrhagiae & Inconclusive & Positive \\
\hline 38 & 47 & M & Confirmed & Icterohaemorrhagiae & Icterohaemorrhagiae & Icterohaemorrhagiae & Positive \\
\hline 39 & 19 & M & Negative & Negative $^{a}$ & - & Negative & Negative \\
\hline
\end{tabular}

$a$ : only one serum sample; $b$ : presumptive serovar; M: male; F: female. 
of the patients and the case interpretations. By PCR, the etiology was defined in 23 of the 39 (58.97\%) patients with aseptic meningitis. Anti-leptospiral antibodies were detected in 13 (33.33\%) CSF samples. Twelve CSF samples were positive by PCR and negative by MAT. Two CSF samples were positive by MAT assay and negative by PCR assay. The positive and negative agreement between both tests was 11 and 14, respectively. CSF samples from six negative cases were positive by PCR. Eight cases showed positive results by PCR, MAT and by serology. Based on serology, 12 patients (30.7\%) were considered to be confirmed cases of leptospirosis and one patient was considered as probable case. No serum samples were obtained from 10 patients and 11 patients had single serum samples. The sensitivity of the PCR assay, based on MATconfirmed diagnoses of leptospirosis, was $89.5 \%$ (Sackett et al. 1991). All leptospiral cultures were negative. The majority of patients with aseptic meningitis were in the age group of 3-19 years (30.77\%). No information about age was available for eight patients. Thirty-one $(79.49 \%)$ patients were males.

\section{DISCUSSION}

Leptospirosis is an important health problem in many countries, including Brazil. The prognosis of leptospiral meningitis is unknown. Studies report mortality rates of 26\% (Mathew et al. 2006). The rapid detection of suspected meningitis is critical for determining an appropriate treatment, but confirming the diagnosis of leptospiral meningitis is often difficult, particularly in developing countries, where there are numerous causes of meningitis (Schlech 1992, Mourvillier \& Wolff 2006, Arnoni et al. 2007, Lammie et al. 2009, Khatami \& Pollard 2010, Kim 2010, Lin \& Safdieh 2010, Marí et al. 2010). An initial presumptive diagnosis is normally made on the basis of clinical observations and then culture of leptospires and MAT are used to confirm the diagnosis (Faine et al. 1999). Unfortunately, culture techniques that permit the isolation of Leptospira spp require up to 13 weeks of incubation (Levett 2001). The presence of non-viable leptospires in the CSF or the slow growth of leptospires may explain the negative culture results in this study. Thus, rapid bacteriological diagnosis of leptospiral meningitis with these conventional techniques is nearly impossible. In addition, few lumbar punctures are performed when the patient presents at the hospital and prompt antibiotic treatment could account negative culture results, as leptospires may no longer be available after antibiotic therapy (Faine et al. 1999). Nevertheless, confirmation of the diagnosis remains essential for appropriate treatment of the patient. We used PCR to detect leptospires in patients with aseptic meningitis as part of their differential diagnosis. PCR is a particularly powerful technique because it does not depend on the presence of viable organisms and can be used routinely in cases of meningeal abnormalities. Our results suggest that PCR can be useful for diagnosing leptospiral meningitis. From 39 patients studied, the test identified the etiology in 23 CSF samples. Simplified extraction procedures were used to reduce the time for extraction to less than $2 \mathrm{~h}$. The implementation of PCR assays for diagnostic purposes is essential due to a change in clini- cal management. In the present study, PCR was demonstrated to be more sensitive than MAT for diagnosis since it detected six additional cases and allowed the diagnosis of leptospirosis from the 3rd-26th day after illness onset. MAT was only capable of diagnosing leptospirosis after 12 days. Twelve CSF samples were positive by PCR and negative by MAT and two CSF samples were positive by MAT and negative by PCR. The phase of the illness is critical to the accuracy of these techniques.

The detection of leptospire DNA by PCR in the CSF of patients with meningitis of unknown etiology has been previously demonstrated (Romero et al. 1998). This study is novel in that we attempted to isolate leptospires and analyzed serum samples by MAT with a new set of patients. Our results are in agreement with other studies showing that patients with aseptic meningitis tend to be younger than those with icteric leptospirosis (Beeson \& Hankey 1952, King \& Urquhart 1975). In Brazil, there is little available data on the meningitis caused by leptospires (Amato Neto et al. 1982, Romero et al. 1998, Silva et al. 2002, de Souza et al. 2006), demonstrating the importance of the study. We demonstrated that PCR has great diagnostic potential, is superior to MAT, and should be applicable to the diagnosis of acute leptospiral meningitis. The implementation of PCR for diagnostic purposes is of paramount importance for patients with leptospiral meningitis, which can go undiagnosed by conventional methods. When all diagnostic tests are combined, the number of confirmed cases should increase. Our results show that clinicians should consider leptospirosis as a possible cause of aseptic meningitis and that molecular tools have the potential to aid in early detection and treatment.

\section{ACKNOWLEDGEMENTS}

To Dr Décio Diament, for helping with statistical analysis and for helpful discussions, and Dr Randy Johnson, for reviewing the text.

\section{REFERENCES}

Amato Neto V, de Avila CA, Kawarabayashi M 1982. Leptospira meningitis: cases reported in the city of São Paulo, during an epidemic outbreak of meningococcal disease. Rev Inst Med Trop Sao Paulo 24: 322-325.

Arnoni MV, Berezin EN, Sáfadi MA, Almeida FJ, Lopes CR 2007. Streptococcus pyogenes meningitis in children: report of two cases and literature review. Braz J Infect Dis 11: 375-377.

Avery RA, Frank G, Eppes SC 2005. Diagnostic utility of Borrelia burgdorferi cerebrospinal fluid polymerase chain reaction in children with Lyme meningitis. Pediatr Infect Dis J 24: 705-708.

Bäckman A, Lantz P, Rädström P, Olcén P 1999. Evaluation of an extended diagnostic PCR assay for detection and verification of the common causes of bacterial meningitis in CSF and other biological samples. Mol Cell Probes 13: 49-60.

Beeson PB, Hankey DD 1950. "Benign aseptic meningitis" as a manifestation of leptospiral infection. Trans Assoc Am Physicians 63: $130-135$.

Beeson PB, Hankey DD 1952. Leptospiral meningitis. AMA Arch Intern Med 89: 575-583.

Bigham RS Jr 1953. Benign aseptic meningitis due to Leptospira grippotyphosa; second report of clinical infection in the United States. AMA Arch Intern Med 92: 587-590. 
Corrêa MO, Hyakutake S, Natale V, Tiriba A da C, Martirani I, Galvão PA, Albano A, de Filippi J, Farhat CK, Neto VA 1971. Human leptospirosis due to Leptospira andamana. Rev Inst Med Trop Sao Paulo 13: 137-143.

de Almeida SM, Nogueira MB, Raboni SM, Vidal LR 2007. Laboratorial diagnosis of lymphocytic meningitis. Braz J Infect Dis 11: 489-495.

de Souza AL, Sztajnbok J, Marques SR, Seguro AC 2006. Leptospirosis-induced meningitis and acute renal failure in a 19-month-old male child. J Med Microbiol 55: 795-797.

du Plessis M, Smith AM, Klugman KP 1998. Rapid detection of penicillin-resistant Streptococcus pneumoniae in cerebrospinal fluid by a seminested-PCR strategy. J Clin Microbiol 36: 453-457.

Faine S, Adler B, Bolin C, Perolat P 1999. Leptospira and leptospirosis, 2nd ed., MediSci, Melbourne, 272 pp.

Faucher JF, Hoen B, Estavoyer JM 2004. The management of leptospirosis. Expert Opin Pharmacother 5: 819-827.

Feigin RD, Anderson DC 1975. Human leptospirosis. CRC Crit Rev Clin Lab Sci 5: 413-467.

Gollop JH, Pang L, Sasaki DM 1990. Leptospirosis: a possible cause of "aseptic meningitis". Hawaii Med J 49: 162-165.

Karande S, Patil S, Kulkarni M, Joshi A, Bharadwaj R 2005. Acute aseptic meningitis as the only presenting feature of leptospirosis. Pediatr Infect Dis J 24: 390-391.

Khatami A, Pollard AJ 2010. The epidemiology of meningococcal disease and the impact of vaccines. Expert Rev Vaccines 9: 285-298.

Kim KS 2010. Acute bacterial meningitis in infants and children. Lancet Infect Dis 10: 32-42.

King SD, Urquhart AE 1975. Laboratory investigations on four cases of leptospiral meningitis in Jamaica. West Indian Med $J$ 24: $196-201$.

Kitaoka M, Hyakutare S, Mori M 1976. Identification of Leptospira andamana isolated from the spinal fluid of a fatal case of leptospirosis in São Paulo, 1963. J Hyg Epidemiol Microbiol Immunol 20: 437-442.

Lammie GA, Hewlett RH, Schoeman JF, Donald PR 2009. Tuberculous cerebrovascular disease: a review. J Infect 59: 156-166.

Levett PN 2001. Leptospirosis. Clin Microbiol Rev 14: 296-326.

Lin AL, Safdieh JE 2010. The evaluation and management of bacterial meningitis: current practice and emerging developments. Neurologist 16: 143-151.

Lorino G, Lilli D, Rivanera D, Guarino P, Angeletti S, Gherardi G, Filadoro F 1999. Polymerase chain reaction, with sequencing, as a diagnostic tool in culture-negative bacterial meningitis. Clin Microbiol Infect 5: 92-96.

Margall Coscojuela N, Majó Moreno M, Latorre Otín C, Fontanals Amyerich D, Domínguez García A, Prats Pastor G 2002. Use of universal PCR on cerebrospinal fluid to diagnose bacterial meningitis in culture-negative patients. Eur J Clin Microbiol Infect Dis 21: 67-69.

Marí JM, Ruiz MP, Anza DV 2010. Laboratory diagnosis of lymphocytic meningitis. Enferm Infecc Microbiol Clin 28 (Suppl. 1): $56-61$.

Mathew T, Satishchandra P, Mahadevan A, Nagarathna S, Yasha TC, Chandramukhi A, Subbakrishna DK, Shankar SK 2006. Neuroleptospirosis - revisited: experience from a tertiary care neurological centre from south India. Indian J Med Res 124: 155-162.
Mérien F, Amouriaux P, Perolat P, Baranton G, Saint Girons I 1992. Polymerase chain reaction for detection of Leptospira spp in clinical samples. J Clin Microbiol 30: 2219-2224.

Merwick A, Kelly S, Galvin R 2008. Meningitis due to leptospiria hardjo-identifying a treatable cause of aseptic lymphocytic meningitis. Ir Med J 101: 91.

Mourvillier B, Wolff M 2006. Infectious meningitis and meningoencephalitis in the adult. Rev Prat 56: 1927-1932.

MS - Ministério da Saúde 2007. [homepage on the Internet]. [accessed 24 April 2010] Available from: portal.saude.gov.br/portal/arquivos/pdf/leptos_casos.pdf.

Nelsen S, Sealy DP, Schneider EF 1993. The aseptic meningitis syndrome. Am Fam Physician 48: 809-815.

Ni H, Knight AI, Cartwright K, Palmer WH, McFadden J 1992. Polymerase chain reaction for diagnosis of meningococcal meningitis. Lancet 340: 1432-1434.

Romero EC, Bernardo CC, Yasuda PH 2003. Human leptospirosis: a twenty-nine-year serological study in São Paulo, Brazil. Rev Inst Med Trop Sao Paulo 45: 245-248.

Romero EC, Billerbeck AE, Lando VS, Camargo ED, Souza CC, Yasuda PH 1998. Detection of Leptospira DNA in patients with aseptic meningitis by PCR. J Clin Microbiol 36: 1453-1455.

Romero EC, Blanco RM, Galloway RL 2009. Application of pulsedfield gel electrophoresis for the discrimination of leptospiral isolates in Brazil. Lett Appl Microbiol 48: 623-627.

Romero EC, Yasuda PH 2006. Molecular characterization of Leptospira sp. strains isolated from human subjects in São Paulo, Brazil using a polymerase chain reaction-based assay: a public health tool. Mem Inst Oswaldo Cruz 101: 373-378.

Sackett DL, Haynes RB, Guyatt GH, Tugwell P 1991. Clinical epidemiology: a basic science for clinical medicine, 2nd ed., Little Brown and Company, Boston, $441 \mathrm{pp}$

Sakata EE, Yasuda PH, Romero EC, Silva MV, Lomar AV 1992. The serovars of Leptospira interrogans isolated from cases of human leptospirosis in São Paulo, Brazil. Rev Inst Med Trop Sao Paulo 34: 217-221.

Saravolatz LD, Manzor O, VanderVelde N, Pawlak J, Belian B 2003. Broad-range bacterial polymerase chain reaction for early detection of bacterial meningitis. Clin Infect Dis 36: 40-45.

Schlech WF 3rd 1992. The epidemiology of bacterial meningitis. Antibiot Chemother 45: 5-17.

Silva HR, Tanajura GM, Tavares-Neto J, Gomes MM de L, Linhares AA da C, Vasconcelos PF, Ko AI 2002. Aseptic meningitis syndrome due to enterovirus and Leptospira sp. in children of Salvador, Bahia. Rev Soc Bras Med Trop 35: 159-165.

Sperber SJ, Schleupner CJ 1989. Leptospirosis: a forgotten cause of aseptic meningitis and multisystem febrile illness. South Med $J$ 82: $1285-1288$

Torre D, Giola M, Martegani R, Zeroli C, Fiori GP, Ferrario G, Bonetta G 1994. Aseptic meningitis caused by Leptospira australis. Eur J Clin Microbiol Infect Dis 13: 496-497.

WHO - World Health Organization 1999. Leptospirosis worldwide, 1999. Wkly Epidemiol Rec 74: 237-242.

Zambrano Y, Chiarello A, Soca A, Villalobos I, Marrero M, Soler M, Laferte J, Alvarez M 2006. Use of polymerase chain reaction for the diagnosis of central nervous system infections. Invest Clin 47: 337-447. 